\title{
Correction to: The Black Campus Movement
}

Ibram X. Kendi

This book has been updated to reflect a change in the author's name from Ibram Rogers to Ibram X. Kendi since the original publication.

The updated online version of the original book can be found at https://doi.org/ 10.1057/9781137016508.

I.X. Kendi, The Black Campus Movement, DOI 10.1057/9781137016508_11, (c) Ibram X. Kendi, 2019 